\title{
THE NUREMBERG LEGACY IN THE NEW MILLENNIUM
}

\section{WinTON HigGINS}

[T] hese defendants now ask this Tribunal to say they are not guilty of planning, executing, or conspiring to commit this long list of crimes and wrongs. They stand before the record of this trial as blood-stained Gloucester stood by the body of his slain king. He begged the widow, as they beg of you: 'Say I slew them not.' And the Queen replied, 'Then say they were not slain. But dead they are...' If you were to say of these men that they are not guilty, it would be as true to say there has been no war, there are no slain, there has been no crime. Robert Jackson, US chief prosecutor, closing address to the International Military Tribunal, Nuremberg, 26 July, 1946

It is the virtue of the Nuremberg trial that it was conceived in hatred of war, and was nurtured by those starved of peace. To realise how grateful we should be for this birth, consider the alternative. - Rebecca West

The 1945-1946 trial of major German perpetrators before the International Military Tribunal in Nuremberg has often been called the greatest trial in history. More than the prominence the major protagonists, the principles at stake guaranteed its historical importance. For the very first time the entrenched principles of state sovereignty and raison d'état came under challenge. In Nuremberg, state functionaries faced prosecution stripped of the impunity that had hitherto attached to state crimes. And they were forced to answer for actions that had hitherto self-evidently constituted prerogatives of a sovereign state, above all starting wars and massacring their own subjects-actions now declared so felonious as to attract the ultimate penalty. Nor were the orders of state functionaries any longer able to shield perpetrators from criminal liability.

In short, the Nuremberg enterprise sought to strengthen the rule of law and to extend it beyond state borders - to 
contribute to an international rule of law - to the extent that all individuals were answerable as moral and legal agents, no matter who they were, the circumstances under which they wronged others, or where they did so. In this new dispensation, every serious, deliberate wrong must attract a public and palpable legal sanction, one imposed on the perpetrator under fair procedures, in order to inhibit like wrongs in the future and to develop a particular kind of society-civil society, or 'civilisation'. The Anglo-American expression of this ideal hails back to the Magna Carta of 1215, conceived as a bulwark against tyranny, and includes early expressions (the American Declaration of Independence of 1776 and that country's Bill of Rights of 1791 prominent among them) of what later came to be known as human rights.

From its inception, the International Military Tribunal (hereafter 'the tribunal' or 'the IMT') had its detractors, and like most pioneering ventures, it had manifold shortcomings and rough edges for its critics to snipe at. Conservative lawyers have objected to the trial's theory and practice, especially its readiness to try defeated enemies for uncodified crimes; while later historians have criticised the way in which the trial wrote the first draft of the history of the Third Reich, including the Holocaust. Yet the trial irrevocably changed the international moral and legal climate. Together with contemporaneous moves to establish universal human rights and outlaw genocide, it made the world less safe for perpetrators. And at the dawn of the present century it gained the sort of successor that leading Nuremberg prosecutors agitated for in their later careers - a permanent international criminal court.

But also in the current century, the Nuremberg heritage has acquired a surprising, intimate opponent to add to the more predictable rogues' gallery of perpetrators and perpetrator states that have always condemned and defied it. The new opponent is none other than the American government, which back in 1945 took the leading role in establishing the tribunal, and in subsequent years took sole responsibility for mounting important precedent-setting further trials in 
Nuremberg against separate categories of German perpetrators. The current American recalcitrance towards the international rule of law, especially international criminal law, poses a considerable threat to the historical authority of the Nuremberg trial, and of course, to the efficacy of its successor, the fledgling International Criminal Court (ICC).

In these adverse circumstances we need to retrieve the original inspiration for the trial, what was thereafter achieved in Nuremberg, and the immediate circumstances and wider historical context in which the tribunal handled its remit. ${ }^{1}$ On this basis we can give its achievements and shortcomings their due proportion, as well as appreciate the tribunal's place in a wider pattern of formative international initiatives in the crucial years immediately following World War II. Just how 'grateful' should we be, in terms of Rebecca West's epigraph,' and thus how resolute need we be in defending the Nuremberg legacy against its current opponents? This essay addresses these questions.

\section{New York lawyers plan a war-crimes trial}

Telford Taylor opens his magisterial account of the trial with the observation that a group of New York lawyers, all at the time US wartime federal officials, laid down the principal ideas and innovations that crystallised in the four-power

1 The following account sketches the direct antecedents of the IMT only. For a wider perspective on how the issue of war crimes developed during the second world war, see Kochavi, Arieh (1998), Prelude to Nuremberg: Allied war crimes policy and the question of punishment, Chapel Hill \& London, University of North Carolina Press.

2 The quote comes from her 'Foreword' to Neave, Airey (1978), Nuremberg: A personal record of the trial of major Nazi war criminals in 1945-6, London, Hodder \& Stoughton, 7. 
Intergovernmental Agreement and Charter signed in London on 8 August 1945 - the charter which came to constitute and govern the tribunal. ${ }^{3}$ They did so in the autumn and winter of 1944-1945. The then US president, Franklin Delano Roosevelt ('though we do not usually think of him as a lawyer') heads his list of the lawyers in question, which naturally also includes the most passionate, eloquent and creative of the tribunal's progenitors, Justice Robert Jackson of the Supreme Court, the immediate past US attorney-general. The others held posts in the departments of State, Treasury, and War; some also held senior ranks in the armed forces, including the Office of Strategic Services (OSS, forerunner of the CIA). ${ }^{4}$ Henry Stimson-a distinguished member of the New York bar, prominent member of the Republican establishment, and US Secretary of State from 1929 to 1933 -led the crucial campaign to prosecute war criminals before an international tribunal based on 'at least the rudimentary aspects of the Bill of Rights, namely, notification to the accused of the charge, the right to be heard and, within limits, to call witnesses in his defense' ${ }^{5}$ In the upshot, the trial would fulfil these criteria.

${ }^{3}$ The group enjoyed the encouragement and assistance of the Institute of Jewish Affairs: see Marrus, Michael (2006), 'A Jewish Lobby at Nuremberg: Jacob Robinson and the Institute for Jewish Affairs', in The Nuremberg Trials: International criminal law since 1945, (eds) Reginbogin, Herbert and Safferling, Christoph, Munich, K G Saur.

4 Taylor, Telford (1993), The Anatomy of the Nuremberg Trials, London, Bloomsbury, 4 . The OSS connection has often been underestimated. Its founder and director, General William ('Wild Bill') Donovan was one of the New York lawyers in question, and the trial would open with him acting as Jackson's deputy. Those working for Donovan at the OSS included Franz Neumann, the author of the groundbreaking 1942 study of the nature of the Nazi state, Behemoth, and Raphael Lemkin, who gave genocide its name and contributed greatly to the 1948 UN Genocide Convention.

${ }^{5}$ Henry Stimson, memorandum of 9 Sept 44 , quoted in Shawcross, 
With military victory in sight, these lawyers were grappling with how to give effect to the Allied foreign ministers' Moscow declaration of November 1943. Most Allied decision-makers assumed that, as soon as practicable, national courts in Europe would punish war crimes committed within their jurisdictions according to the laws of the land. For that purpose, captured suspects were to be sent back to the scenes of their crimes for trial according to those laws. But what of the main criminals, those whose activities transcended national borders? According to the Moscow declaration, they would 'be punished by a joint decision of the Governments of the Allies'. ${ }^{6}$ This declaration was one of a series of general threats issued by Allied leaders during the war to try to ameliorate the Third Reich's already notorious, large-scale atrocities. ${ }^{7}$

From the German military catastrophe at Stalingrad in the winter of 1942-1943, after which any informed German could infer that the war would end badly, such threats may have had some psychological impact. But they fell well short of a specific plan to punish the major war criminals. Among America's allies, the punishment of war crimes hardly loomed large, with the only other serious suggestion for giving effect to the Moscow declaration being the 'political' rather than judicial one espoused by the British government: draw up a list of principal Nazi perpetrators to be shot on capture and positive identification. This proposal also enjoyed support in the USA from, among others, the influential Treasury

Hartley (1995), Life Sentence: The memoirs of Lord Shawcross, London, Constable, 88.

${ }^{6}$ Quoted in Taylor, 27. In what follows I draw on Taylor's both insider and highly scholarly account of the background to the London charter (chapters 1-2), as well as on Shawcross, chapter 7.

${ }^{7}$ For the history of these threats and declarations, see Kochavi. 
Secretary, Henry Morgenthau Jr. Only Stalin evinced any enthusiasm for a trial, and his conception thereof - based on his own infamous show trials at home, ones with only one possible outcome - fell well short of due process as defined by the US Bill of Rights.

Henry Stimson and his New York lawyers eventually overwhelmed their opponents at home and abroad through their assiduous planning and bold conception of a pioneering jurisprudence around the issues the Third Reich so starkly posed: the waging of aggressive war as such, war crimes proper, and crimes against humanity (including attempts to wipe out whole peoples, not least the Jews of Europe). As Jackson would put it in his opening address to the tribunal, in his own inimitable 'winged words':

The real complaining party at your bar is Civilization... [It] asks whether law is so laggard as to be utterly helpless to deal with crimes of this magnitude by criminals of this order of importance. It does not expect that you can make war impossible. It does expect that your juridical action will put the forms of international law, its precepts, its prohibitions and, most of all, its sanctions, on the side of peace, so that men and women of good will, in all countries, may have 'leave to live by no man's leave, underneath the law.' 8

In particular, the architects of the coming trial had to overcome 'Civilization's' dispiriting experience during and after World War I-an experience which throws this new ambition to create an international rule of law into dramatic relief.

Back then, the law was so 'laggard' that when the Allies in May 1915 issued a joint declaration condemning the Turkish authorities' ongoing massacre (or 'genocide' in the later coinage) of the Armenians, they did so knowing that this atrocity broke no international law: under the 'Westphalian'

${ }^{8}$ Quoted in Taylor, 171-72. Jackson himself is quoting from Rudyard Kipling's 1899 poem, The Old Issue. 
principle of national sovereignty, a nation-state could persecute and massacre its own subjects at will, just as it could start and wage wars in pursuit of state policy. All the perpetrators of the Armenian genocide, bar one officer sentenced to death by a Turkish court-martial in 1919, were amnestied under the treaty of Lausanne of 1923. At the end of the war, Germany's 12 war-crimes trials in Leipzig in 19211922, held under the provisions of the treaty of Versailles, ended in fiasco. The New York lawyers were all too painfully aware, as well, that attempts to extend the rule of law to international affairs after the first world war, and to establish an international court with criminal jurisdiction, 'foundered on the rocks of American opposition,' as Taylor puts itabove all America's refusal to join the League of Nations and to encourage the institutional creativity it stood for. ${ }^{9}$

The legal coterie around Stimson in 1944-1945 worked from first principles. It made interwar attempts to outlaw war as such the leitmotiv of the trial it sought. ${ }^{10}$ Fundamentally evil in itself, war was also understood as the fons et origo of all the other evils the trial would highlight; for this reason, aggressive war (or 'crimes against peace') became the centrepiece of the trial. War created the pretexts and opportunities - as well as the veil of secrecy - for war crimes and crimes against humanity, which constituted the other two heads of German mass criminality.

But the scale of the criminality on all three counts, and the problem of what or whom to put in the dock, of how to

${ }^{9}$ Ibid, 16.

10 Stimson himself had served as Secretary of State previously, in Herbert Hoover's administration (1929-33), and keenly supported the Kellogg-Briand pact, whereby its principal signatories, and later 44 other signatory states, renounced war as an instrument of national policy: Kochavi, 229. 
spread the net wide enough, called for considerable creativity. The Allies themselves would inevitably dissolve the two main institutional perpetrators - the Third Reich and the Nazi Party - as they formally did on 8 May 1945 under the terms of the German surrender; the Allies would then exercise their own sovereignty over Germany, and no German state would remain to prosecute. Ultimately individuals had to be brought to book, potentially in large numbers.

Colonel Murray Bernays of the Army General Staff came up with a compelling suggestion: charge the leading Nazis with the old common-law offence of conspiracy to commit felony, namely, that of unleashing aggressive war; and empower the intended tribunal to declare the principal perpetrator organisations to be criminal organisations, thus making all their members prima facie guilty of indictable offences for the purposes of subsequent prosecutions of lower-ranking perpetrators. Importantly, this step would bring domestic atrocities committed by members of these organisations against their own compatriots within the purview of international criminal law. At the same time, Colonel William Chanler-Stimson's partner in a New York law firm, but now deputy director of US military government in Europe - assembled the argument close to Stimson's heart: international initiatives during the interwar period, , the 1928 Kellogg-Briand pact, had criminalised the waging of aggressive war, which thus now constituted 'crimes against the peace' in international law.

These suggestions, which came to be called 'the Nuremberg ideas', won Roosevelt's favour. After his death in April 1945, his successor, Harry Truman, continued to support Jackson's project along these lines, albeit without FDR's enthusiasm and specialist competence. In the last dramatic week of the war in Europe, the drama was by no means limited to that theatre of war. On 2 May 1945, Truman appointed Jackson 'representative of the United States and chief of counsel' for the purposes of bringing a war-crimes trial to fruition. The next day the British cabinet withdrew its 
support for the 'political solution' to the war-crimes problem, partly because Hitler, Himmler and Goebbels among others had already killed themselves, and were thus no longer available for demonstrative execution. This decision left the way open for an in-principle agreement, made that same day at a meeting of the foreign ministers of the Big Three, to hold an international trial as the Americans and Soviets had wanted. The foreign ministers were meeting in San Francisco, where the inaugural congress of the United Nations was in progress. As Jackson's son William, who would also join the US prosecution team in Nuremberg, later remarked on this historical coincidence:

It is perhaps not commonly apprehended that the principles of Nuremberg...go hand in hand with the organization of the United Nations as the twin foundation of an international society ordered by law. ${ }^{11}$

'The Nuremberg ideas' were ideas whose time had come.

\section{The devil and the detail}

Before they saw the light of day in court these ideas had to be tested and honed in difficult negotiations on just how such a trial would proceed, and the procedural principles it would apply. Representatives of the four intended prosecuting and judging nations (the French had now agreed to join the venture) met in London 15 times between 26 June and 8 August 1945. This 'conference' saw a clash of three quite different conceptions of law and trial procedure.

The Americans (headed by Jackson) and the British (led by the attorney-general, Sir David Maxwell Fyfe) ${ }^{12}$ shared the common-law tradition in which judge-made law played an

${ }^{11}$ Quoted in Taylor, 42.

${ }^{12}$ Later the Earl of Kilmuir, Lord Chancellor 1954-62. 
obvious part in proliferating and adapting a legal system, and the adversarial trial process-including rigorous crossexamination-constituted the royal road to just (and thereby unpredictable) trial outcomes. For these two delegations, the trial was intended precisely to set a precedent that would extend international law. But this approach was foreign to continental traditions, in which law had purely legislative sources, including explicit codes, and trials proceeded along inquisitorial rather than adversarial lines. Heated arguments thus broke out over the proposed counts of conspiracy and crimes against peace in particular, as no existing continental code supported them. As well, the Soviet negotiators could not contemplate the possibility of acquittals, and had no taste for criminalising aggressive wars as such, only 'Hitlerite' ones.

Jackson's talents did not extend to diplomacy, and Maxwell Fyfe's own diplomatic skills were sorely tried as he chaired the meetings and mediated between Jackson on the one hand, and the French and Soviet representatives on the other. Jackson was determined to defend the whole package of ideas he had arrived with, and made no bones of his government's intention to mount the trial alone if the other powers did not accept it. He regarded Soviet participation as unhelpful in any event. The USSR had without provocation invaded both Poland and Finland in late 1939, andaccording to contemporary Western intelligence, since confirmed - was responsible for the Katyn Forest massacre of between eight and eleven thousand Polish officers found buried there. And yet its representatives were deter-mined to join in the prosecution of 'Hitlerite' aggressive war, and to sheet home the Katyn massacre to the German defendants. The chief Soviet delegate, General I T Nikitchenko (an army judge advocate who would become the senior Soviet judge at the trial) clearly had his orders from home, but faced an uncompromising American negotiator who would have received a Soviet withdrawal from the project with equanimity. 
Before and during these difficult negotiations in London, Jackson manifested a moral and political passion that would infect his British counterpart and affect the way both would discharge their functions at the trial itself. For his part, Jackson had on 7 June 1945, at the president's behest, published a report which clearly stated his position. It alluded to the fact that US authorities held the most significant war criminals in custody, which made it the country's 'inescapable responsibility' to deal with them in the most high-minded way possible.

To free them without trial would mock the dead and make cynics of the living. On the other hand we could execute and otherwise punish them without a hearing. But undiscriminating executions or punishments without definite findings of guilt, fairly arrived at, would violate pledges repeatedly given, and would not sit easily on the American conscience or be remembered by our children with pride. The only other course is to determine the innocence or guilt of the accused after a hearing as dispassionate as the times and horrors we deal with will permit, and upon a record that will leave our reasons and motives clear.

Jackson's concern for 'the record' was crucial: he already feared a future denialism, which only 'a well documented history' could thwart. In Nuremberg, he would make Nazi documents, photographs and film footage the core of the American case.

Unless we write the record of this [Nazi] movement with clarity and precision, we cannot blame the future if in days of peace it finds incredible the accusatory generalities uttered during the war. We must establish incredible events by credible evidence. ${ }^{13}$

Maxwell Fyfe, who would for practical purposes lead the

${ }^{13}$ Quoted in Taylor, 53-54. 
British prosecution team in Nuremberg, shared the same concern, and to a large extent the same approach. As he wrote in his memoirs:

[E]very devil has his advocate. We have seen apologists for everything. It is, therefore, just as well that in respect of Nazi war crimes the apologist of the future will be confronted by the admissions of the many accused found guilty, and the mass of incriminating documents produced at the trials, whose authenticity has been established by the very men who wrote them. Both devil and advocate are faced by an unscaleable barrier of truth. ${ }^{14}$

The coming trial would precipitate a scramble for documentary evidence of unprecedented proportions, and the German authorities' obsessive documentation would guarantee its success.

Gradually the logic of the uneven negotiating positions in London asserted itself. The French had no concrete counterproposals, and indeed would maintain a low profile throughout the trial. The Soviets had no reasonable counter-proposals, and were easily isolated. On 26 July the results of the British elections of 5 July were announced: Labour had won a crushing victory, and was even more enthusiastic about the American approach to the war-crimes problem than their outgoing Tory counterparts. Sir Hartley Shawcross, the new Labour attorney-general, replaced Maxwell Fyfe as the London Agreement and Charter approached fruition, though the former, now destined to become the British chief prosecutor at the trial, quickly appointed the latter as his deputy.

On 8 August the agreement was signed. The charter it endorsed embodied all the New York lawyers' principles; as well, it proved itself in the main to be a coherent and workable constitution for the tribunal and guide to its

${ }^{14}$ Kilmuir, Lord (1964), Political Adventure: The memoirs of the Earl of Kilmuir, London, Weidenfeld \& Nicholson, 126. 
procedure. ${ }^{15}$ Its coherence rested on its special indebtedness to Anglo-American conceptions of law and judicial procedure. At the same time, it contained all the features which, then as now, stirred legal controversy, not least among legal conservatives: the element of retrospectivity in the counts dealing with conspiracy and crimes against peace (article 6), the withdrawal of individual impunity for state crimes and for following orders (articles 7 and 8), and the suggestion of 'guilt by association' in the provision for indicting organisations which, if held criminal, would lay the basis for prosecutions of individuals on the basis of membership alone (articles 9 and 10). ${ }^{16}$ As against these claims, as Shawcross would later stress in his closing address to the tribunal, the charter's only innovation was 'to provide the long-overdue machinery to enforce already-existing law' ${ }^{17}$

15 Taylor, 75. His one substantive criticism concerns the charter's failure to specify grounds of defence available to defendants in subsequent trials who are charged with membership of organisations declared criminal by the IMT: loc cit.

16 Bradley Smith presents one of the most influential legal critiques of the trial in his Reaching Judgment at Nuremberg, New York, Basic Books, 1977. He also argues that the Anglo-American carpetbombing of German towns and cities (including Nuremberg itself) robbed the Allies of the moral authority to try German war criminals at all. While the bombing is today widely recognised as a war crime, it was not seen in this light around the end of the war. And since misguided military doctrines partly motivated it, and it involved heavy Allied casualties, it hardly compares with most of the crimes with which the Nuremberg defendants were charged. Its death toll of 600,000 civilians is appalling, yet amounts to a tenth of the Holocaust's, to say nothing of Nazi Germany's other prisoner of war and civilian massacres.

17 Shawcross, 119. The term 'holocaust' was first used to describe the 1896 massacre of Armenians under Sultan Hamid II; it was not a Jewish term or a Jewish-chosen one. 
As we have seen, the New York lawyers had already anticipated and argued most of these points at length, but perhaps the former's ultimate vindication lies in Rebecca West's challenge, quoted at the beginning of this essay: consider the alternative. Undoubtedly that alternative, bar a few summary executions, would have closely resembled the dispiriting outcomes of attempts to bring war criminals to book after the first world war, and the law would have remained 'laggard' in the face of incomparably larger crimes.

To read the charter now, together with the 18,000-word indictment based on it (signed on 18 October and served on the defendants the next day), we might be surprised to find so little made of the Jewish genocide. Its extent was known to the Nuremberg prosecutors, who led the appropriate incontrovertible evidence during the trial. But in fact Raphael Lemkin had only coined the term 'genocide' the year before it began; ${ }^{18}$ his influence as a member of the US prosecution team led to the term finding its first official use in the Nuremberg indictment. Genocide became a distinct crime in international law only with the widespread ratification of the 1948 UN Convention on the Prevention and Punishment of the Crime of Genocide. And the concept and term 'the Holocaust' for a distinct catastrophe only became international common coin in the 1970s and 1980s. ${ }^{19}$ The charter was signed just two months after the war in Europe ended; it reflected the then current perception that the persecution and slaughter of European Jewry merged into a pattern of breathtaking criminality which also included widespread massacres of millions of prisoners of war and non-Jewish civilians, including the Romani and other ethnic groups, throughout German-occupied Europe.

${ }^{18}$ See Lemkin, Raphael (1944), Axis Rule in Occupied Europe, Washington, Carnegie Endowment for International Peace.

${ }^{19}$ Novick, Peter (2000), The Holocaust and Collective Memory: The American experience, London, Bloomsbury, 19-20. 
Compared to the charter, the indictment based on it was marred by haste and the inordinate number of lawyers engaged in its drafting. Its worst blemish consisted in extending the conspiracy count to all the other counts, such that some defendants were charged with devising a 'common plan' to commit war crimes and crimes against humanity as well, not crimes against the peace only as the charter envisaged. As well, the Soviets insisted on including the Katyn Forest massacre in the indictment. (In the end, they adduced no evidence for this charge, and the judges passed over it in silence.) But beyond that, even the indictment was a serviceable document which centred on four enumerated counts: conspiracy ('the common plan'), crimes against peace, war crimes proper, and crimes against humanity.

Selection of the defendants provided the least propitious feature of the trial preparation. Through bungling and miscommunication, Gustav Krupp, the aged and senile patriarch of the Krupp empire-foremost exploiter of the Reich's 4,795,000 foreign slave workers who had toiled and perished in large numbers in its war industries - was indicted instead of his son Alfried, who in fact owned and controlled the conglomerate during the war. ${ }^{20}$ The tribunal would quickly rule the former too incapacitated to proceed against, and block his replacement with Alfried on procedural

${ }^{20}$ Major Airey Neave - a young English war hero and barrister led the initial investigation of the Krupp concern in mid-1945 on behalf of the British War Crimes Commission. His account of it in Nuremberg: A personal record of the trial of major Nazi war criminals in 1945-6, London, Hodder \& Stoughton, 1978, makes salutary reading about the Krupp atrocities (including its exploitation of Auschwitz inmates) and the management's compact moral indifference towards them that he encountered after the war. He later played an important part in the trial assisting the bench, including taking evidence on commission. 
grounds. Thus no representative of German war industry came to sit in the dock during the trial-its greatest shortcoming.

Another mistake was indicting the radio journalist Hans Fritzsche, of the propaganda ministry, as a surrogate for the dead Joseph Goebbels, Nazi Germany's propaganda minister. The Western Allies held Otto Dietrich, Goebbels's immediate subordinate, but the Soviets insisted on charging the comparatively lowly Fritzsche as a matter of national pride: they had only one other major war criminal to contribute to the collection in the Nuremberg dock, Admiral Erich Raeder. ${ }^{21}$ Yet another mistake was to proceed with an indictment in absentia against Martin Bormann, Hitler's official secretary and manager of Party affairs who vanished when Berlin fell on 2 May 1945, and probably died that day in the fighting while escaping Hitler's bunker.

Nonetheless, when the trial began on 20 November 1945, 21 defendants sat in the dock. They represented the Reich's political, military and organisational elite, its governors of conquered territories, and its propagandists. Notionally the SS, SA, Gestapo, Reich cabinet, and military general staff and high command also sat in the dock, indicted as criminal organisations. In front of the dock sat legal representatives for each individual and organisational defendant.

\section{Isolation, discomfort and friction in Nuremberg}

I have emphasised above the extraordinary vision and determination that American policy-makers around Henry Stimson, the Secretary of War, brought to the formulation of US policy on war crimes 1944-1945, to the London negotiations, and to the drafting of the charter that emerged from them. With Jackson leading the 1,200-strong US prosecution team (and the authority figure for the wider

${ }^{21}$ Taylor, 631. The tribunal ended up acquitting Fritzsche. 
American contingent of around 1,700) in Nuremberg, that determination was, if anything, redoubled, as the world was now watching. If the trial was to set an invaluable precedent in international criminal law, it could not proceed in obscurity; it needed to present a salutary spectacle reported by hundreds of radio and newsprint correspondents, expert commentators, and a considerable number of dignitaries from around the world. The British and American prosecutors in particular were conscious of the performative dimension of the trial-they were playing to the galleries of their home publics, and after that, of international public opinion. Legal criteria would soon clash with dramatic desiderata, as we will see.

American negotiators had to fight hard to gain agreement for the choice of Nuremberg, in the American zone of occupation, as the seat of judgment. The natural choice, as the Soviets insisted, was the German capital, Berlin, in their own zone. As a face-saving compromise, Berlin became the 'headquarters' of the IMT, under the wing of the Allied Control Council there. The preliminary sessions of the IMT were thus held in Berlin from 9 October 1945, ending nine days later with the approval and signing of the prolix indictment, after which the actual trial was adjourned to Nuremberg. Here the occupying US Third Army could protect and resource it as trial participants in their hundreds began to arrive from the four host powers and from other parts of Germany, and correspondents flocked in from all corners of the developed world. For this purpose, the army set up a special administrative zone, the Nuremberg-Fürth enclave.

Once there, the prosecutors, judges and their staffs found themselves virtually isolated. There was little land transport in or out of Nuremberg, as the ravages of war had destroyed infrastructure, and the various occupation zones across Germany set up a maze of travel and currency restrictions. Air transport was in short supply because so many Allied 
pilots had already been demobilised. In any event, Allied governments were preoccupied with the more immediate issues of postwar reconstruction and had no interest in trying to influence the trial's course from afar. The Western governments in particular made no attempt to influence the proceedings or their outcome. ${ }^{22}$

These circumstances meant that the fate of the whole Nuremberg project now very much lay in the hands of the people on the ground. If their skill or dedication faltered, the trial could descend into chaos or farce, and a vital opportunity for the development of international law and human rights would be lost.

The physicality of Nuremberg intimately impinged on the trial participants as they struggled to remain focused, faced their dilemmas and shouldered their responsibilities. ${ }^{23}$ Ninety per cent of the old town lay in ruins after 11 Allied heavy bombing raids on this city of elegant Romanesque and HighGothic buildings, and toy and gingerbread factories. For 500 years it had served as the effective seat of government for the mediaeval 'first reich', the Holy Roman Empire, so Hitler chose it as the symbolic heart of his own 'thousand-year' Third Reich. The city's name attached to the notorious Nazi race laws that Hermann Göring as president of the Reichstag proclaimed there in 1935. Up to 1938 annual Party rallies and mock battles were staged on the Zeppelin Field on the city's outskirts; grandiose monumental masonry, some of it bearing the fingerprints of the architect and trial defendant Albert

22 Shawcross, 122.

23 The main prosecutorial memoir writers all comment on the confronting environment, but the best descriptions of it come from two outstanding writers who covered the trial for The New Yorker: Rebecca West and Janet Flanner; see West (1955), A Train of Powder, London, Macmillan, and Flanner (1979), Janet Flanner's World:

Uncollected writings 1932-1975, Irving Drutman (ed), New York and London, Harcourt Brace Jovanovich, 98-145. 
Speer, still stood there to bear witness to the short-lived Nazi power and glory. Allied airforce and army commanders seem to have recognised Nuremberg's symbolic status, which warranted their own special attention. The US Seventh Army overwhelmed the ferocious resistance of two Waffen-SS divisions to seize the city on Hitler's 56th birthday, 20 April 1945 , ten days before he shot himself. Now the city had been chosen to host a new drama, the day of reckoning.

Nazi Germany had not committed resources to recovering the dead from bombsites or to providing prosthetic limbs for its own war amputees. The new arrivals in Nuremberg were assaulted not only by startling images of mass destruction, but by the stench of around 6,000 corpses rotting under the rubble, rat plagues and the sight of the limbless crawling over the rubblescape, often living in cellars and bomb shelters beneath it. For want of any other burial place, relatives of the dead placed paper lanterns and candles in the rubble of last known addresses on the anniversary days of the dead beneath. ${ }^{24}$ Jackson would note in his opening address at the trial, as he warmed to his central theme:

It is not necessary among the ruins of this ancient and beautiful city with untold numbers of its civilian inhabitants buried in its rubble, to argue the proposition that to start or wage an aggressive war has the moral qualities of the worst of crimes. ${ }^{25}$

For the thousands of new arrivals whose business was the

24 West, 30.

${ }^{25}$ Quoted in Taylor, 171. As he notes (262), 'For Jackson, the establishment of crimes against peace as an acknowledged part of international law was the crux of the entire case. The British supported that goal.' It was also the crux of Shawcross's opening address on 3 December 1945. 
trial and who passed through this devastation each day, the city itself bore mute testimony to the trial's own iron necessity.

Though most of the trial participants lived better than the local population, their everyday lives were spartan, even by immediate postwar European standards. There was nothing to buy and nowhere to buy it except flea markets and outlets for rationed food, although American troops also had access to their ubiquitous do-gooder PX stores. The makeshift cafeteria in the Palace of Justice (Justizgebäude) served basic army food to 1,500 people each sitting day at lunchtime, though the high-ranking could do a little better at the Grand Hotel, which the occupiers had hastily refurbished as the social centre for the trial. The trial itself ran from 20 November 1945 to 1 October 1946 to a back-breaking schedule, sitting with only short breaks from 10 am to $5 \mathrm{pm}$ on weekdays, and some Saturday mornings. In all, it held 216 sitting days.

Social and cultural life was minimal for lack of time, resources and camaraderie between the national delegations. The only exceptions were a high level of working cooperation and after-hours socialising between the American and British delegations, and the French started a much appreciated nightclub in the outer suburb of Zirndorf where they, along with the British, occupied requisitioned villas. The 35 German defence lawyers, of whom 14 admitted to being Nazi Party members, found their way onto nobody's invitation list. The self-isolating Soviet delegation did not do much better.

Under all these circumstances, the trial hardly unfolded as the smooth, natural and rational process that today's peace studies and human rights idealists might see in the rear-vision mirror. It lived and breathed makeshift and conflict. Prosecutors and judges all came from diverse traditions and backgrounds, and engaged in rivalry and hostility while discharging their separate functions. These conditions 
coloured the internal workings of the huge American prosecution team under Jackson's irascible and highly dysfunctional management. ${ }^{26}$ And between prosecution and defence lawyers reigned mutual incomprehension. Especially in the latter stages of the trial, the defendants themselves jostled each other in shifting struggles for influence and authority, as well as engaging in mutual blame-shifting as they presented their individual defences.

But makeshift and conflict did not weaken the trial - they were its condition of existence, its lifeblood. Anna Tsing argues that it is precisely friction - 'the awkward, unequal, unstable, and creative qualities of interconnection across difference' - that brings to life real-world global encounters. Friction provides the 'traction' or 'grip' that move international projects forward, while at the same time challenging the dubious universalisms that (in her idiom) give rise to dreams of the seamless evolution of a benign international order. ${ }^{27}$ It is perhaps this sort of imaginary orderly development that the legal critics of the Nuremberg trial have always hankered after. Jackson anticipated them in his opening address:

This Tribunal, while it is novel and experimental, is not the product of abstract speculations nor is it created to vindicate legalistic theories. This inquest represents the practical effort of four of the most mighty of nations, with the support of seven-teen more, to utilise international law to meet the

26 Taylor, especially 136-42 and 182. Six days after the trial began Jackson sacked General Donovan, a major figure in the Stimson group and the prosecution team, and a steady stream of senior figures resigned in exasperation as the trial proceeded.

27 Tsing, Anna (2005), Friction: An ethnography of global connection, Princeton and Oxford, Princeton University Press, 4. 
greatest menace of our times - aggressive war. ${ }^{28}$

\section{The trial}

As indicated, the scale of the Nuremberg trial beggars comparison. Though the prosecution case was overwhelmingly documentary (including photographic and cinematographic material), it still called 33 witnesses, while the defence summoned 61. The tribunal generated its own documents, especially as it needed multiple copies of all written material in each of four languages. The English version of the daily transcripts alone fills 17,000 pages. In all, the trial produced 50 million pages of typing and 4,000 recorded discs. ${ }^{29}$ A new professional corps, simultaneous interpreters, made its debut and constituted the nervous system of this multilingual institution.

The bench consisted of two judges from each of the four powers - a voting judge, and an alternate who sat through the proceedings in case his senior became indisposed. The judges were of varying experience and ability, and the alternates tended to be the better lawyers, or to have more judicial experience, than their seniors. Sir Geoffrey Lawrence, a lord justice of the British Court of Appeal, presided, and thus ran the court during sittings. Though perhaps 'much better known as a country squire with a good stable than as a great lawyer', in Shawcross's words, ${ }^{30}$ Lawrence made an invaluable contribution through his unfailing courtesy and firmness. He became a popular figure among the defendants, in whose favour his procedural rulings tended to err. They were not to know that, in the common-law tradition, this is usually a bad sign that the judge senses which is the weaker party and redoubles his or her efforts to be make the probable

${ }^{28}$ Excerpted in Owen, James (2006), Nuremberg: Evil on trial, London, Headline Review, 34.

29 Shawcross, 107-08.

30 Shawcross, 100. 
outcome appear fair.

The prosecution bore the burden of proof the whole way. Under the agreed division of labour between the prosecution teams, the Americans were responsible for proving the first count of the indictment (conspiracy); the British count two (crimes against peace); and the French and Soviets shared counts three and four (war crimes and crimes against humanity), with the French responsible for proving crimes committed in Western Europe and the Soviets for those committed in the east. The Americans' task here was easily the most demanding, in terms of both legal theory and evidence.

Not surprisingly, the proceedings were dominated, at least until the defence case began, by the huge American prosecution team. It would send no less than 23 of its number to the lectern to handle various aspects of their case; all of them, including their leader, tended to be indifferent or inexperienced trial advocates, though Jackson's legal vision, passion and oratory soared above the rest of the legal fraternity assembled there. The British team, though only 163 strong and thus a seventh the size of its American counterpart, deployed complementary skills. Apart from the usually absent Shawcross (who delivered only the opening and closing addresses on his team's behalf), the British sent just six seasoned barristers to the lectern throughout the trial. They were led by the veteran criminal advocate Sir David Maxwell Fyfe, who also shone as an administrator behind the scenes. As the tribunal applied Anglo-American court procedure, both these teams found themselves on home ground. The French and Soviet teams were smaller still than the British, and disadvantaged by the unfamiliar procedure.

A detailed account of the proceedings falls outside the limits of this essay and so some highlights must suffice. After the tedious reading of the indictment 'onto the record' on the first two days, Jackson opened the prosecution case with an 
address he later described as the most important talk of my life'; ${ }^{31}$ his was far from the only superlative it would attract. He began right 'on message':

The privilege of opening this first trial in history for crimes against the peace of the world imposes grave responsibility. The wrongs which we seek to condemn and punish have been so calculated, so malignant, and so devastating, that civilisation cannot tolerate their being ignored, because it cannot survive their being repeated. That four great nations, flushed with victory and stung with injury stay the hand of vengeance and voluntarily submit their captive enemies to the judgment of the law is one of the most significant tributes that Power has ever paid to reason. ${ }^{32}$

The speech spellbound the bench, the lawyers and the gallery. Telford Taylor, normally quick to criticise his colleagues (Jackson included), felt that "nothing said at Nuremberg thereafter matched its force, perception and eloquence. Indeed, I know of nothing else in modern juristic literature that equally projects the controlled passion and moral intensity of many passages.' 33 Jackson's opening address thus amply fulfilled both the legal and the theatrical demands on the trial.

These contrasting demands soon collided as the American prosecutors began to lead their evidence. Proceedings quickly bogged down in the mass of captured German documents tendered, and serious logistical problems arose in making them available in multiple copies to all parties in the four languages that the tribunal used. The press and public seating emptied, and the bench became irate as 'reading documents onto the record' took up day after day. In normal proceedings, this tendering of hard documentary evidence would

${ }^{31}$ Quoted in Taylor, 172.

32 Excerpted in Owen, 34

33 Taylor, 167. 
have constituted best practice, but in Nuremberg it threatened to defeat a major purpose of the trial.

Gradually the tribunal developed ways to handle documents more expeditiously, and the American team became more selective in the documents it tendered. It also began to introduce other forms of evidence. These included the gruesome films taken by the British when they liberated the Bergen-Belsen concentration camp, and by the Americans when they overran Buchenwald and Dachau. To the outrage of those in the dock, the American prosecutors also called high-ranking German officers who testified to the military defendants' complicity in Hitler's war planning and in atrocities against civilians.

The British prosecutors had the advantages of a more circumscribed task in establishing crimes against peace, and of a very tight organisation; they called no witnesses and accomplished their task in four days. To the surprise of most, the senior French prosecutor, François de Menthon, delivered a brilliant, impassioned opening address on 17 January 1946, one that deeply impressed his audience, even the defence lawyers. But reading it 40 years later, Taylor notes 'a jarring omission of reference to Jews and the Holocaust', despite de Menthon's identifying 'racialism' as the worst aspect of Nazism. ${ }^{34}$ The Soviet prosecution presented powerful evidence of German atrocities in eastern Europe, including a surprise star witness - Field Marshall Friedrich Paulus, who led the German forces in the disastrous Stalingrad campaign-and a documentary film recording German atrocities in the USSR, one even more horrifying than those screened by the American prosecution.

The trial had then reached what the British alternate judge,

34 Taylor, 296. 
Sir Norman Birkett, described in his diary as 'in a very real sense, the critical moment of the trial' - the opening of the defence case, starting with Reichsmarschall Hermann Göring, commander-in-chief of the Luftwaffe, founder of the Gestapo, and Hitler's longtime intimate and heir apparent. ${ }^{35}$ Legally speaking, this was not the critical moment. The prosecution case against this defendant was already formidable, and his evidence-in-chief did not seek to refute it, but rather to enter a long and fiery defence of Hitler and Nazism; it thus contained corroborating admissions. Göring never wavered from the view that a death sentence was certain, and he participated in the trial only to expose it as a sham and to speak to a resurgent German posterity which, he believed, would hail him and his ilk as heroes, exemplars and martyrs.

But Birkett was right about 'the critical moment', as he was arguably not only the best jurist in the courtroom, but also keenly aware of how the trial was unfolding as a morality play writ large. In this sense, he saw Göring fulfilling a pivotal role, as he noted in his diary:

Throughout this trial the dead Hitler has been present at every session, a dreadful, sinister, and in some respects inexplicable figure; but Göring is the man who has really dominated the proceedings, and that remarkably enough, with-out ever uttering a word in public up to the moment he went into the witness box... [I]t has been obvious that a personality of outstanding though possibly evil qualities, was seated there in the dock. 36

In his own diary, the prison psychologist Gustave Gilbert confirms Göring's dominance among the defendants as he marshalled them to a common cause and stance. Like many others, he also notes Göring's dramatic transformation in

${ }^{35}$ Quoted in Hyde, H Montgomery(1964), Norman Birkett: The life of Lord Birkett of Ulversten, London, Penguin, 509.

${ }^{36}$ Quoted in Hyde, 510. 
American captivity, from a besotted, grossly obese drug addict, to a man of normal build, great charm, forceful personality and very high intelligence. ${ }^{37}$

Though cross-examination was unnecessary from an evidentiary point of view, from a dramatic one it would have been unthinkable for Göring's grandstanding in his own evidence-in-chief over two and a half days to have gone unchallenged. To a packed courtroom, Jackson rose to tackle him on 18 March 1946. He immediately made elementary mistakes in his cross-examination, posing open-ended questions and challenging Göring's opinions rather than his factual assertions. The latter took the invitation to grandstand once more, humiliating Jackson in the process. Having palpably lost control of the cross-examination, Jackson became even more flustered when his ill-advised appeals to the bench to control the witness were turned down: Göring was within his rights in answering open-ended questions in extenso. He was also playing to his own gallery, his fellow defendants, with great success. Jackson never gained the upper hand, and virtually every commentator and diarist present reported the appalling effect the scene had on those present. Afterwards Jackson 'was well-nigh unhinged by the torrent of criticism', his then deputy, Telford Taylor, comments. ${ }^{38}$ 'For a few hours, the fate of the Nuremberg Trials trembled in the balance', Maxwell Fyfe notes in his memoirs. ${ }^{39}$

He himself was due to cross-examine after Jackson, and suddenly had to assemble new material to recover the ground

37 Gilbert, G M (1947), Nuremberg Diary, New York, Farrer, Strauss \& Co. Gilbert (28) assessed Göring's IQ as 138.

38 Taylor, 344 .

${ }^{39}$ Kilmuir, 113. 
Jackson had lost. After a night of frantic preparation, Maxwell Fyfe began his own duel with Göring. Transposed to the former's usual places of work, what followed would have rated as little more than a workmanlike cross-examination by an experienced advocate who was on top of his brief and held some good cards. There were no open-ended questions, only questions of factual detail, the answers to which the advocate already held in his hand; and the witness's attempts at diversionary sallies were abruptly cut off.

In this particular setting with this particular witness, however, the interchange amounted to high-order courtroom pyrotechnics. Maxwell Fyfe had his own gallery to play tothe British public - and highlighted Göring's collusion in the murder of 75 recaptured RAF officers who had escaped from Stalag Luft III. He pressed his increasingly cowed prey into admissions that revealed the Reichmarschall as a heartless warmonger and murderer, a common liar, and a disgrace to any officer corps worthy of the name. In her dispatch to The New Yorker, Janet Flanner reported from the press gallery:

During this vital cross-examination, Sir David's professional affability disappeared...With his excellent mind, his vast legal knowledge, and the added passion of a just inquisition, he stood behind his lectern and prosecuted the seated Göring into at least a partial state of destruction. He succeeded in doing what had not yet been done: he forced Göring to separate himself intellectually from the Nazi myth, he forced him to admit the difference between the glorified Nazi plan and the ghastly human results. 40

${ }^{40}$ Flanner, 120. Maxwell Fyfe admitted in his memoirs (Kilmuir, 97), that Göring was 'without question the most formidable witness I have ever cross-examined'. Owen (132-70) excerpts selections of the transcript of Göring's cross-examination. In a bizarre rewriting of history, Yves Simoneau's 2000 docudrama, Nuremberg, attributes Maxwell Fyfe's cross-examination to a resurgent Jackson (played by Alec Baldwin). 
It was now clear to lay spectators - as it had long been clear to the lawyers - that Göring's position was hopeless. He lost his grip on the other defendants, who in turn abandoned all solidarity with each other.

As the other defendants now took turns to present their individual defences, they shifted blame onto each without restraint, to the prosecution's advantage. And those who chose to step into the witness box faced the nemesis of Maxwell Fyfe, who in effect now replaced the wounded Jackson as the central figure at the prosecution tables. ${ }^{41}$

The judges took a month of frequent, long meetings to reach their verdicts, agree on sentences and write their judgment applying the principles expressed in the charter. In the upshot they acquitted three of the 21 defendantsFritzsche, Schacht and von Papen. The German police would soon re-arrest them and submit them to new court proceedings, in the Spruchkammer of the denazification program. Each of the remaining 18 defendants was convicted on at least one count; 11 received death sentences, and seven received long custodial sentences.

After their appeals to the Control Commission in Berlin failed, the 11 condemned men kept their appointment with the US Third Army's hangman in the early hours of 16 October 1946, except for Göring who took his own life two hours earlier. The remaining defendants found their way to Spandau prison in the British zone of Berlin. International criminal law had not only made its entrance; it came armed with palpable sanctions as Jackson had called for. ${ }^{42}$

41 Taylor, 633.

42 Well ahead of public opinion at the time, both Jackson and Shawcross were prominent opponents of the death penalty in their respective countries. Given the scale of the criminality before the 
The judges cleaned up the confusion in the indictment around the conspiracy count. The charter sought to apply this count to aggressive war only, and the tribunal now reinstated the charter's more restrictive approach. It also refused to declare the Reich cabinet and German high command to be criminal organisations, as they did not constitute 'organisations' in the strict sense (the cabinet in particular had not met since 1937), and were small enough for individual prosecutions to suffice. The Allies' denazification program would trump the tribunal's adverse verdicts against the SS, SA and Gestapo in the treatment of 'lesser' criminals in the years to come. ${ }^{43}$

\section{The main Nuremberg trial in historical context}

Around the time of the Nuremberg trial, the Allies conducted many other war-crimes trials in Europe along more conventional lines, the most prominent being those the British conducted in Belsen and the Americans in Dachau. More importantly, the original 'Nuremberg ideas', as expressed in the charter and the tribunal's judgment, were enshrined in international law as 'the Nuremberg principles' adopted by the UN General Assembly on 11 December 1946. For three years after the trial ended, these principles and the precedent the trial had set were applied in 11 important subsequent trials of separate categories of German perpetrators. These trials were held under purely American auspices (with Telford Taylor now chief of counsel), also in the Palace of Justice in Nuremberg.

When the cold war began in earnest in 1948, the major powers' pursuit of geopolitical interests soon closed the valuable opening for progressive international initiatives that arose at the end of World War II. As we have seen, the

Nuremberg tribunal, however, it was not a suitable forum in which to raise this issue.

43 Taylor, 628. 
protagonists of the first Nuremberg trial seized this shortlived opportunity. But they were not alone in so doing. The founders of the United Nations, and the drafters of its Universal Declaration of Human Rights (UDHR) and abovementioned Genocide Convention (both adopted by its General Assembly in December 1948) built on the Nuremberg principles, and on the precedent the trial set.

The UDHR is perhaps the clearer case in point. From the US Declaration of Independence of 1776, with its famous 'selfevident truths' about equal human dignity and rights, authoritative bodies in several countries had impotently declared and proclaimed human rights in the absence of effective sanctions for their breach. The Nuremberg trial established the first supportive sanctions against major forms of human rights transgression. With that background, the UN gave its Human Rights Commission, formidably chaired by Eleanor Roosevelt, the task of drafting a declaration of universal rights. ${ }^{44}$ Like the trial itself, the workings of the commission and its drafting committee generated friction in generous proportions, as Mary Ann Glendon's account makes clear: the intensifying east-west and Arab-Jewish conflicts contributed greatly to the drafting committee's dynamism up to the UDHR's unanimous adoption by the UN General Assembly in $1948 .{ }^{45}$ In her speech to the Assembly on that

44 Reginbogin, Herbert and Safferling, Christoph (2006), The Nuremberg Trials: International criminal law since 1945, Munich, K G Saur, 13.

45 Glendon, Mary Ann (2001), A World Made New: Eleanor Roosevelt and the Universal Declaration of Human Rights, New York, Random House. See also Winton Higgins (2012), 'Human Rights Development: Provenance, Ambit and Effect', in (eds) Dudley, Michael, Silove, Derrick and Gale, Fran, Mental Health and Human Rights: Vision, praxis and courage, Oxford, Oxford University Press. 
occasion, Roosevelt commended the declaration for its potential to 'become the international Magna Carta of all men everywhere'. ${ }^{46}$ Before Nuremberg, its adoption would have been an empty gesture; after 1948, the project itself would not have been politically feasible. Once this valuable platform was in place, however, the elaboration of an international rule of law could proceed under the human rights agenda during and after the cold war, albeit at a slower pace. Subsequent UN conventions against torture and slavery, and asserting the rights of women, children and refugees, among others, also build on the Nuremberg principles and the UDHR in fleshing out inter-national legal protections and responsibilities.

As we have seen, the progenitors of the Nuremberg trial highlighted the need for sanctions for breaches of international criminal law, which presupposed the existence of a court with jurisdiction over all potential perpetrators. As Jackson noted in his opening address at Nuremberg, in an apology for the necessity, faute de mieux, for victors being left to try the vanquished:

We must never forget that the record on which we judge these defendants is the record on which history will judge us tomorrow. To pass these defendants a poisoned chalice is to put it to our own lips as well. 47

Shawcross and Taylor, among others active in the prosecution at Nuremberg, were conscious of this issue and so agitated for a permanent international criminal court to succeed the IMT. ${ }^{48}$ Only in the 1990s did we see ad hoc warcrimes trials in the Nuremberg lineage under the aegis of the $\mathrm{UN}$, ones covering atrocities, including genocide, in Rwanda and former Yugoslavia. Since then, the UN has also initiated

${ }^{46}$ Quoted in Glendon, 166

${ }^{47}$ Quoted in Taylor, 168.

48 See Shawcross, 137; Taylor, 641 
similar criminal proceedings in Sierra Leone and Cambodia in partner-ship with the national governments in question.

The idea of a permanent international criminal court remained alive in the UN General Assembly, and came to fruition in the 1998 Statute of Rome, which set up today's International Criminal Court in the Hague - the Nuremberg tribunal's logical and more robust successor. ${ }^{49}$

\section{'The end of America'}

In sum, the founding of the UN, the Nuremberg trial and the UDHR, taken together, represent a dramatic leap forward in creating an international rule of law intended to uphold rights-including the right to peace, security and individual inviolability-and to impose criminal sanctions on their breach. The country that contributed the lion's share to this remarkable mid-twentieth century development was America. Fittingly, the UN was founded in San Francisco; American officials took the lead in devising and nurturing the Nuremberg project; and the UDHR was drafted on the shores of Lake Success, New York, under the leadership of one of the country's twentieth-century national treasures, Eleanor Roosevelt. This startling achievement reversed the USA's dismal interwar record of recalcitrance towards the League of Nations and towards proposals to develop an international criminal law, complete with an international court to enforce it. The country achieved an historically unprecedented moral authority.

Unfortunately, the old interwar recalcitrance seeped back into American political culture in the latter half of the twentieth century, so weakening institutions that prominent

${ }^{49}$ Kaul, Hans-Peter, 'The International Criminal Court: Key Features and Current Challenges', in Reginbogin and Safferling eds, op cit. 
Americans had nurtured in the latter half of the 1940s. The country has thus turned on its own progeny, and thereby defiled its own founding ideals of individual rights, the rule of law and due process. It certainly gives comfort to perpetrators, including those who commit genocide. When this recalcitrance reached its climax in the early 2000s subverting peace, human rights and the rule of law both at home and abroad - it is no wonder that Naomi Wolf describes the process in a book entitled The End of America. ${ }^{50}$

Successive US administrations have refused to ratify many important ramifications of international law, including UN covenants (and optional protocols to them) setting up the UN Human Rights Committee, seeking to abolish the death penalty, discrimination against women and torture, and ones in defence of the rights of children and migrant workers. The US has broken ranks with the rest of the Western world in retaining capital punishment and reintroducing torture as a routine recourse for its military and intelligence services, and its faux-judicial military commissions in Guantánamo Bay may admit evidence extracted under torture in its planned show trials - a throwback to the pre-1770s judicial torture in Western Europe. ${ }^{51}$ Unordinary rendition program' whereby it abducts targeted individuals from any country to be tortured

50 Wolf, Naomi (2007), The End of America, Melbourne, Scribe, 2007.

51 The widespread US use of torture (and its provenance in directives issued by the former defence secretary Donald Rumsfeld and attorney-general Alberto Gonzales, with the connivance of the president) was confirmed in the report of the (bipartisan) US Senate Armed Services Committee Inquiry into the Treatment of Detainees in US Custody, published on 11 December 12, 2008. As the report notes, in a memorandum of 7 February 2002, Bush arbitrarily suspended the protections of the third Geneva Convention in the treatment of supposed Al Qaida and Taliban detainees, thus rendering them rightless. See also Sands, Philippe (2008), Torture Team: Deception, cruelty and the compromise of law, London, Allen Lane. 
in client states, such as Egypt, where this practice is a normal part of quotidian governance.

America was one of just seven countries (with China, Iraq, Israel, Libya, Qatar, and Yemen) which voted against the 1998 Treaty of Rome and the establishment of the ICC. At the last minute (31 December 2000), the Clinton administration signed it, but the incoming Bush administration refused to ratify it. Quite the contrary, it has chosen the route of outright defiance of the ICC, not least in 2002, the year the court came into existence, with the adoption of the American ServiceMembers' Protection Act, the express purpose of which is 'to protect United States military personnel and other elected and appointed officials of the United States government against criminal prosecution by an international court to which the United States is not a party.' The legislation, which has attracted the sobriquet 'The Hague Invasion Act', in particular authorises the President to use 'all necessary and appropriate means to bring about the release of any US or allied personnel being detained or imprisoned by, or on behalf of, or at the request of the International Criminal Court'. It also prohibits any co-operation with ICC investigations. The impunity that the Nuremberg project denied perpetrators is thus reinstated as far as American power reaches. The days when that 'power paid tribute to reason' are now long gone - to return to Robert Jackson's opening words to the Nuremberg tribunal cited above.

America and its closest allies showed their contempt for the Nuremberg legacy in their unprovoked invasion of Iraq in 2003 - the specific crime of waging aggressive war, the central issue in the Nuremberg trial, the crime for which the tribunal sentenced eight individuals to death in 1946. As Geoffrey Robertson comments, 'The Bush Administration regarded international law as a set of rules that applied to other 
countries.' 52 Ironically, the American and British governments invoked the Nuremberg principle on the criminality of aggressive war in justifying the first Gulf war after Iraq invaded Kuwait in August 1990. ${ }^{53}$

The New York lawyers around Henry Stimson would have found all too familiar the pattern whereby war (even the rhetorical and protean 'global war on terror') provides the occasion and the pretext for war crimes and crimes against humanity of the kind symbolised by the US facilities of Abu Ghraib and Guantánamo Bay. What they would have found unfamiliar, 60-odd years after the Nuremberg trial, is the reversal of roles which has left their own country the most prominent international outlaw. In 1947, Stimson himself wrote:

[I]n the judgment of Nuremberg there is affirmed the central principle of peace - that the man who makes or plans to make aggressive war is a criminal. A standard has been raised to which Americans, at least, must repair; for it is only as this standard is accepted, supported, and enforced that we can move onward to a world of law and peace. 54

But Robert Jackson and the other Nuremberg prosecutors, who went to work each day with the stench of death in their nostrils, would have found themselves in familiar territory with the massive destruction and loss of life of the Iraq waryet another deliberately begun and unwinnable war fought with no holds barred.

For a few hopeful months in 2008, during the US presidential election campaign, it seemed that a line might be drawn under the recalcitrant turn in American political

52 Klatsky Lecture 11 November 2008, extracted in his 'He's Got the Whole World in his Hands, But Can Obama Do It Justice?', Sydney Morning Herald, 13 November 2008.

53 Shawcross, 137.

${ }^{54}$ Quoted in Kochavi, 229-30. 
culture, and an attempt would be made to restore the country's moral authority. The Democratic nominee, Barak Obama, declared his intention, for instance, to close the notorious camp at Guantánamo Bay ('a tremendous recruiting tool for al-Qaida') and end other abuses of the Bush era. As his first term as President now draws to a close, though, Guantánamo is still in business, now graced with Obama's own 2011 executive order legitimating a formal system of indefinite detention without trial. ${ }^{55}$ The same is true of the other transgressive institutions Obama inherited from Bush'extraordinary rendition', 'enhanced interrogation techniques', the faux-judicial 'military commissions' that bar access to properly constituted courts, and of course 'the Hague Invasion Act'.

On 2 May 2011, Obama sent troops on a mission that had them violate the borders of an allied country, gun down Osama bin Laden in his bedroom and kneecap his wife, when these troops obviously could have been given the option to arrest their 'target' alive to face trial. Compared to some of the Nuremberg defendants who enjoyed due process, bin Laden was no more than a smalltime crook, and so it is worth recalling Robert Jackson's words quoted above that the former's proposed extra-judicial killing 'would not sit easily on the American conscience or be remembered by our children with pride'. But Jackson was writing of another America, as Wolf's thesis implies. How easily extra-judicial killing sits on the present American conscience can be gleaned from Obama's recent gloating celebration of the anniversary of bin Laden's killing, including his goading his Republican opponent in his second presidential campaign for supposedly lacking the 'ticker' to order an action like this. ${ }^{56}$

55 The Guardian Weekly, 27 April 2012.

56 The Sydney Morning Herald, 2 May 2012. 


\section{International criminal law, peace and human rights now}

Without American passion, creativity and resources, the Nuremberg trial would never have taken place, and William Jackson's ideal of 'an international society ordered by law', quoted above, would have remained an impossible utopia. Miraculously, perhaps, this project has now come far and appears to be still advancing in spite of - though necessarily weakened by - outright American hostility. The ICC has now been ratified by 121 states, and has engaged with the cases of such high-profile perpetrators as the former Bosnian-Serb leader, Radovan Karadzic, Ratko Mladic and the current president of the Sudan, Omar Hassan al-Bashir. The associated human rights project has been developing for much longer, and has been greatly strengthened by the monitoring or 'watch' practices that have arisen out of the Helsinki accords of 1975.57

However, in betraying its own mid-twentieth century handiwork, today's America is the main brake on progress in international law, justice and human rights, and no amelioration of its regressive political culture is in sight. Were a volte face to come to pass, however, the Nuremberg legacy might recover its true proportion in undergirding the international society based on peace, law and rights that its American progenitors foretold.

57 See Higgins, op cit. 